\title{
PREFERENSI RISIKO PETANI PADI DI DAERAH ALIRAN SUNGAI BENGAWAN SOLO, KABUPATEN BOJONEGORO, PROVINSI JAWA TIMUR
}

\author{
Natasa Apriana*)1, Anna Fariyanti**), dan Burhanuddin ${ }^{* *}$ \\ *) Program Studi Agribisnis, Sekolah Pascasarjana, Institut Pertanian Bogor \\ Jl. Raya Dramaga, Gedung Sekolah Pascasarjana IPB, Kampus IPB Dramaga 16680 \\ ${ }^{* *}$ Departemen Agribisnis, Fakultas Ekonomi dan Manajemen, Institut Pertanian Bogor \\ Jl. Kamper Wing 2 Level 5, Kampus IPB Darmaga Bogor 16680
}

\begin{abstract}
Bojonegoro Regency is one of the major sources of food and energy and the 4th largest rice production center in East Java Province; however, it is the most vulnerable region to flood from Bengawan Solo River. The fluctuation of rice production for the last six years shows the existence of rice production risk in Bojonegoro. This research aims to analyze the factors that affect rice production and production risk in Bojonegoro Regency and to analyze the behavior of rice farmers in facing production risk. The data used were secondary data from the Research Center for Disaster of IPB 2016, and the research was held in Kegungprimpen Village, Kanor of Bojonegoro Regency from March-April 2016 with 50 samples from the rice farmers. The data were analyzed using multiple linier regression analysis and absolute risk averse (AR). The results show that the variables of land width, pesticides, and flooding are the increasing risk factors, while those of labor, chemical fertilizer and organic fertilizer are the reducing risk factors. The behavior of farmers in facing the production risk a whole shows that the entire rice farmers in e Kedungprimpen Village are risk takers. Assistance in the use of inputs of pesticides and agricultural insurance are required because they can provide protection to rice farmers as anticipation against rice production risk.
\end{abstract}

Keywords: flood, Bengawan Solo River watershed, preference, risk

\begin{abstract}
ABSTRAK
Kabupaten Bojonegoro merupakan salah satu wilayah lumbung pangan dan energi serta sentra produksi padi tertinggi ke 4 di provinsi Jawa Timur merupakan wilayah yang paling rentan terhadap bencana banjir sungai Bengawan Solo. Fluktuasi produksi selama enam tahun terakhir menunjukan adanya risiko produksi di Kabupaten Bojonegoro. Penelitian ini bertujuan untuk menganalisis faktor - faktor yang memengaruhi produksi dan risiko produksi dan menganalisis preferensi risiko petani padi padi di Kabupaten Bojonegoro. Data yang digunakan adalah data sekunder dari hasil penelitian Pusat Studi Bencana IPB tahun 2016 yang dilaksanakan pada bulan Maret - April 2016 di Desa Kegungprimpen, Kecamatan Kanor, Kabupaten Bojonegoro dengan sampel yang digunakan, yaitu 50 petani padi. Teknik analisis data menggunakan analisis regresi linier berganda dan absolute risk averse (AR). Hasil penelitian menunjukan bahwa variabel luas lahan, pestisida, dan banjir merupakan faktor peningkat risiko (risk increasing factors), sedangkan tenaga kerja, pupuk kimia dan pupuk organik merupakan faktor pengurang risiko (risk reducing factors). Preferensi risiko petani secara keseluruhan menunjukkan bahwa seluruh petani padi yang ada di Desa Kedungprimpen bersifat risk taker. Perlu adanya pendampingan penggunaan input pestisida dan asuransi pertanian yang dapat memberikan perlindungan kepada petani padi sebagai antisipasi terhadap risiko produksi
\end{abstract}

Kata kunci: banjir, das bengawan solo, preferensi, risiko

\footnotetext{
${ }^{1}$ Alamat Korespondensi:

Email: natasaapriana@gmail.com
} 


\section{PENDAHULUAN}

Sungai Bengawan Solo melintasi 2 Daerah Administratif tingkat I, yaitu Provinsi Jawa Tengah dan Provinsi Jawa Timur. DAS Bengawan Solo dibagi ke dalam tiga sub DAS, yang meliputi; Sub DAS Bengawan Solo Hulu, sub DAS Bengawan Solo Madiun, dan sub DAS Bengawan Solo Hilir. Hulu Sungai Bengawan Solo terletak di Kabupaten Wonogiri dan bermuara di Kabupaten Gresik. Kabupaten Bojonegoro merupakan wilayah terluas, sedangkan Kota Madiun merupakan wilayah terkecil.

Purwanto (2014) menyatakan bahwa saat ini kondisi Bengawan Solo mengalami kerusakan yang semakin parah yang menyebabkan risiko banjir. Banjir antara lain disebabkan oleh semakin dangkalnya sungai Bengawan Solo, dikarenakan terjadi sedimentasi baik di hulu maupun di hilir serta tanggulnya mengalami kerusakan akibat erosi (KLH, 2013). Selain itu ketidakpastian iklim menyebabkan banjir sulit untuk diprediksi (Marfai, 2014). Banjir akibat luapan sungai Bengawan Solo terjadi tiap tahun kususnya di daerah hilir mengakibatkan kerugian disektor pertanian (Adisukma, 2014).

Data frekuensi banjir dari BNPB tahun 2016, tercatat sepanjang tahun 2011-2015, Kabupaten Bojonegoro merupakan Kabupaten dengan frekuensi banjir terbanyak dibandingkan dengan wilayah lain, yaitu mencapai 35 kali dengan total kerusakan lahan 8.626 ha. Hal ini menjadikan Bojonegoro masuk dalam wilayah dengan tingkat kerentanan banjir dalam kategori tinggi.

Kabupaten Bojonegoro yang merupakan salah satu wilayah yang rentan terhadap banjir, merupakan salah satu wilayah lumbung pangan dan energi serta sentra produksi padi tertinggi ke 4 di provinsi Jawa Timur dengan kontribusi mencapai 7\%. Peyerapan tenaga kerja pada sektor pertanian di Kabupaten Bojonegoro mencapai 41,6\% (BPS, 2016). Hal ini menunjukan bahwa Sektor pertanian di Kabupaten Bojonegoro memberikan kontribusi yang cukup besar bagi perekonomian wilayah dan cadangan pangan kususnya padi dihadapkan pada adanya risiko produksi akibat dari banjir sungai Bengawan Solo. Adapun perkembangan luas panen, produksi, dan produktivitas padi di Kabupaten Bojonegoro dapat dilihat pada Gambar 1.
Luas panen, produksi, dan produktivitas padi di Kabupaten Bojonegoro pada Gambar 1 terlihat berfluktuatif selama enam tahun terakhir. Terjadinya fluktuasi tersebut diduga disebabkan oleh bencana banjir yang merusak lahan pertanian di Kabupaten Bojonegoro. Risiko produksi dipengaruhi oleh sumber ekstrenal yang tidak dapat ditanggulangi oleh petani seperti bencana alam dan sumber internal yang dapat ditanggulangi oleh petani seperti penggunaan input produksi (Hernanto, 1989). Menurut Fufa dan Hasan (2003) pengaruh gangguan stokastik alam dari kegiatan produksi pertanian menjadi sumber utama risiko produksi. Mahananto et al. (2009) menjelaskan bahwa penggunaan input yang tidak sesuai dengan standar yang dianjurkan dapat memengaruhi hasil yang diperoleh. Lebih lanjut Robinson dan Barry (1987) mengemukakan bahwa hampir setiap proses produksi khususnya produksi pertanian, risiko memainkan peranan yang sangat penting dalam keputusan alokasi penggunaan input yang akhirnya berpengaruh terhadap produktivitas. Keputusan penggunaan input dipengaruhi oleh preferensi risiko petani. Preferensi risiko petani dikelompokkan kedalam tiga sifat, yaitu menyukai risiko (risk taker), netral terhadap risiko (risk netral), dan menghindari risiko (risk averse) (Ellis, 1988). Tujuan dari penelitian ini adalah untuk menganalisis faktor-faktor yang memengaruhi produksi dan risiko produksi padi dan menganalisis preferensi risiko petani padi di Kabupaten Bojonegoro.

\section{METODE PENELITIAN}

Data yang digunakan dalam penelitian ini adalah data sekunder dari hasil penelitian Pusat Studi Bencana IPB tahun 2016 yang dilaksanakan pada bulan Maret - April 2016 di Desa Kegungprimpen, Kecamatan Kanor, Kabupaten Bojonegoro.

Sampel yang digunakan dalam penelitian ini berjumlah 50 responden petani padi yang ada di Desa Kedungprimpen, Kecamatan Kanor, Kabupaten Bojonegoro. Gujarati (2007) menjelaskan rata-rata sampel dari besaran sampel yang terdiri dari sekurangkurangnya 30 observasi akan mendekati normal apapun distribusi probabilitas yang mendasarinya.

Pengaruh penggunaan input terhadap produksi dan risiko produksi padi diidentifikasi menggunakan analisis regresi linier berganda. Risiko produksi diidentifikasi menggunakan nilai variance produksi. Salah satu 
model yang digunakan untuk mengetahui variance produksi, yaitu model Just and Pope (Robinson dan Barry, 1987). Fungsi produksi yang digunakan dalam model ini adalah fungsi produksi Cobb-Douglas dalam bentuk logaritma natural. Adapun fungsi produksi dan fungsi variance produksi padi sebagai berikut:

Fungsi produksi:

$\mathrm{LnY}_{\mathrm{i}}=\alpha_{0}+\alpha_{1} \operatorname{LnX}_{1 \mathrm{i}}+\alpha_{2} \operatorname{LnX}_{2 \mathrm{i}}+\alpha_{3} \operatorname{LnX}_{3 \mathrm{i}}+\alpha_{4} \operatorname{LnX}_{4 \mathrm{i}}+$ $\alpha_{5} \operatorname{Ln} X_{5 \mathrm{i}}+\alpha_{6} \mathrm{D}+\varepsilon_{\mathrm{i}}$

Variance produksi:

$\sigma_{2} Y_{i}=\left(Y_{i}-\hat{Y}_{i}\right)^{2}$

Fungsi variance produksi (risiko):

$\mathrm{Ln \sigma}^{2} \hat{Y}_{\mathrm{i}}=\beta_{0}+\beta_{1} \operatorname{LnX}_{1 \mathrm{i}}+\beta_{2} \operatorname{LnX}{ }_{2 \mathrm{i}}+\beta_{3} \operatorname{LnX}{ }_{3 \mathrm{i}}+\beta_{4} \operatorname{LnX}_{4 \mathrm{i}}+$ $\beta_{5} \operatorname{Ln} X_{5 \mathrm{i}}+\beta_{6} \mathrm{D}+\varepsilon_{\mathrm{i}}$

Keterangan:

$\mathrm{Y}=$ Produsi padi $(\mathrm{kg})$

$\mathrm{X}_{1}=$ Luas Lahan (ha)

$\mathrm{X}_{2} \quad=$ Tenaga Kerja $(\mathrm{HOK})$

$\mathrm{X}_{3}=$ pestisida $(\mathrm{mililiter} / \mathrm{ha})$

$\mathrm{X}_{4}=\operatorname{pupuk}$ oganik $(\mathrm{kg} / \mathrm{ha})$

$\mathrm{X}_{5} \quad=$ pupuk kimia $(\mathrm{kg} / \mathrm{ha})$

$\mathrm{D}=$ Dummy Bencana $(1=$ saat banjir $(\mathrm{MT}$ II tahun 2013) dan $0=$ saat tidak banjir (MT II tahun 2015))

$\sigma^{2} \hat{\mathrm{Y}}_{\mathrm{i}} \quad=\quad$ Variance produksi padi

$\varepsilon=$ error

$\mathrm{I}=$ Petani responden $\alpha_{1} \ldots \alpha_{6}=$ Koefisien parameter dugaan Produksi Rata-Rata X1, X2,..., X5

$\beta_{1} \ldots \beta_{6}=$ Koefisien parameter dugaan Variance produksi X1, X2,..., X5

Pengujian pada penyimpangan asumsi klasik digunakan untuk mendapatkan model terbaik untuk melakukan pendugaan. Pengujian penyimpangan asumsi klasik yang dilakukan adalah pengujian multikolinier, autokorelasi, dan heterokedastis (Gujarati (2002), Firdaus (2011), Setiawan dan kusrini (2010). Gejala multikolinier dilihat dari nilai Variable Inflation Factor (VIF). Apabila nilai VIF pada masing-masing variabel independen memiliki nilai lebih dari 10 maka dapat disimpulkan bahwa dalam model tersebut terjadi multikolinieritas (Susetyo,2012). Gejala autokorelasi pada model dilakukan dengan menggunakan pengujian Durbin-Watson (DW) dan gejala heterokedastisitas diuji menggunakan uji park (Firdaus, 2011).

Koefisien determinasi (R2) digunakan untuk mengetahui tingkat kesesuaian (goodness of fit) model dugaan dan untuk mengetahui seberapa jauh keragaman produksi dan risiko produksi dapat dijelaskan oleh variabel independen yang telah dipilih. Uji signifikansi model dugaan digunakan untuk mengetahui apakah faktor produksi yang digunakan secara bersama-sama berpengaruh nyata terhadap produksi padi. Pengujian model dugaan menggunakan uji F. Uji signifikansi variabel digunakan untuk mengetahui variabel bebas mana saja yang berpengaruh nyata terhadap variabel dependent. Uji yang digunakan, yaitu uji T (Gujarati, 2007).

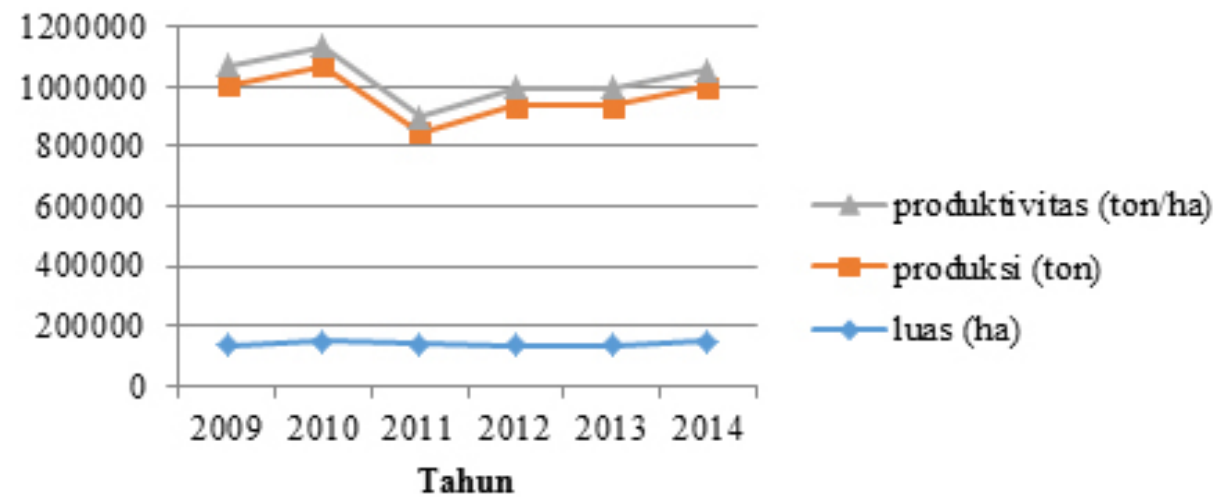

Gambar 1. Luas panen, produksi dan produktivitas padi Kabupaten Bojonegoro tahun 2009-2014 (BPS, 2016) 
Analisis preferensi risiko menggunakan model absolute risk aversion (AR), yang dihubungkan dengan fungsi utilitas yang dimiliki seseorang utilitas petani $(\mathrm{U}(\pi))$. Adapun $\pi$ dirumuskan $\pi=$ p.y - r.x $-\mathrm{C}$

\section{Keterangan:}

$\pi \quad=$ keuntungan usaha tani
$\mathrm{r}=$ harga input
$\mathrm{x}=$ jumlah input yang digunakan
$\mathrm{p}=$ harga output
$\mathrm{y}=$ output
$\mathrm{C}=$ biaya tetap

Output usaha tani (y) dirumuskan $\mathrm{y}=\mathrm{f}(\mathrm{x})+\mathrm{g}(\mathrm{x})$ dengan mensubstitusikan persamaan output usaha tani (y) ke dalam persamaan utilitas petani maka diperoleh:

$$
\mathrm{U}(\pi)=p \cdot f(x)+p \cdot g(x)-r \cdot x-C
$$

Fungsi utilitas $[\mathrm{U}(\pi)]$ adalah :

$$
\mathrm{U}(\pi)=p \cdot f(x 1, \ldots, x 5)+p \cdot g(x 1, \ldots, x 5)-r i(x 1, \ldots, x 5)-C
$$

Keterangan:

$\mathrm{U}(\pi) \quad=$ utilitas petani

$\mathrm{f}(\mathrm{x}) \quad=$ fungsi produksi

$\mathrm{g}(\mathrm{x}) \quad=$ fungsi risiko

$\mathrm{p} \quad=$ harga output (rupiah)

ri $\quad=$ harga input ke-i (rupiah)

$\mathrm{xi}=$ jumlah input ke-i

$\mathrm{C}=$ biaya tetap

Untuk menganalisis nilai preferensi risiko petani dengan mengadopsi Arrow-Pratt absolute risk averson (AR). Adapun $\mathrm{AR}$ dirumuskan $\mathrm{AR}=\left(\mathrm{U}^{\prime \prime}(\pi)\right) /\left(\mathrm{U}^{\prime}(\pi)\right)$. Pengambil keputusan dikatakan bersifat risk averse apabila nilai AR (y) $>0$, risk neutral apabila AR (y) $=0$, dan risk taker apabila AR $(\mathrm{y})<0$ (Kumbakar, 2002).

\section{Hipotesis}

Hipotesis untuk fungsi produksi

$\mathrm{H} 0: \alpha=0$

H1 : Ada salah satu $\alpha$ yang tidak sama dengan 0 . Artinya, semakin luas lahan, semakin banyak tenaga kerja, pestisida, pupuk kimia, dan pupuk organik yang digunakan serta saat kondisi normal maka produksi padi akan meningkat.
Hipotesis untuk fungsi risiko produksi

$\mathrm{H} 0: \beta=0$

H1 : Ada salah satu $\beta$ yang tidak sama dengan 0 . Artinya, semakin luas lahan, semakin banyak tenaga kerja dan pestisida yang digunakan dalam proses produksi maka risiko produksi padi semakin menurun. Namun, semakin banyak pupuk organik dan pupuk kimia yang digunakan dalam proses produksi serta saat terjadi bencana banjir maka risiko produksi padi semakin meningkat sehingga luas lahan, tenaga kerja, dan pestisida dikategorikan sebagai faktor yang menurunkan risiko (riskreducing factors). Selanjutnya, pupuk organik, pupuk kimia dan bencana banjir dikategorikan sebagai faktor yang meningkatkan risiko (risk inducing factors).

\section{HASIL}

\section{Gambaran Umum Wilayah}

Desa Kedungrimpen memiliki lahan pertanian seluas 386 ha yang terdiri dari tanah sawah berpengairan tekhnis 325 ha, tanah kering untuk bangunan 44 ha, tegal ladang 14 ha dan lain-lain 6 ha. Selain pertanian, Desa Kedungprimpen juga memiliki potensi perternakan (sapi, kambing, dan itik) sebagai penghasilan sampingan petani dan usaha kotoran ternak yang digunakan sebagai pupuk organik. Selain penghasil komoditas padi, Kedungprimpen juga memproduksi kacang tanah, jagung, ubi, dan lainnya dari hasil pengelolaan hutan bersama masyarakat.

Pada umumnya pola tanam padi di Desa Kedungprimpen 2 kali dalam setahun, yaitu musim tanam I berlangsung pada bulan Juni-September dan musim tanam II berlangsung pada bulan Oktober-Januari. Selain itu terdapat juga musim banjir yang berlangsung pada bulan Februari-April. Namun, saat ini waktu kedatangan banjir tidak bisa diperkirakan karena terjadi perubahan iklim. Banjir bisa datang pada bulan Desember saat padi berumur 60-70 hst (musim tanam II tahun 2013) dan bisa datang pada bulan Februari saat petani telah panen (musim tanam II tahun 2015). Banjir akan merugikan petani apabila datang saat padi berumur 60 70 hst. Produktivitas padi tertinggi terjadi pada musim tanam I, yaitu mencapai 10 ton/ha. Produktivitas pada musim tanam II, hanya mencapai 8 ton/ha. Namun, produktivitas padi di Desa Kedungprimpen lebih besar dibandingkan dengan produktivitas rata-rata Kecamatan Kanor, yaitu 7,12 ton/ha (BPS Bojonegoro, 2016). 


\section{Karateristik Responden}

Karakteristik responden terdiri dari umur, tingkat pendidikan, pengalaman usaha tani, dan luas lahan. Berdasarkan umur responden, $88 \%$ petani masuk dalam kategori umur produktif, yaitu antara 40-60 tahun. Sedangkan untuk tingkat pendidikan, 50\% petani lulusan Sekolah Dasar. Petani di desa Kedungprimpen sudah lama menjadi petani, terlihat dari persentase pengalaman usaha tani petani $74 \%$ telah menjadi petani selama lebih dari 20 tahun. Luas lahan petani sampel $50 \%$ berada dalam rentan $0,5-2$ ha.

Faktor-Faktor yang Memengaruhi Produksi dan Risiko Produksi Padi

Hasil uji asumsi klasik menunjukan bahwa fungsi produksi dan fungsi risiko produksi diketahui bahwa model tidak terdapat multikolineartas, autokorelasi, dan heterokedastis. Hasil pendugaan persamaan fungsi produksi dan fungsi risiko produksi dapat dilihat pada Tabel 1.

Hasil pendugaan pada Tabel 1 maka fungsi produksi padi dan fungsi risiko produksi padi dapat diduga dengan persamaan sebagai berikut:
Fungsi Produksi

$\operatorname{LnY}=4,856+0,141$ Ln Luas + 0.1 LnTenaga kerja 0,176 Ln Pestisida + 0,136 LnPupuk organik + 0,655 LnPupuk kimia - 2,384 Dummy bencana

Fungsi Risiko

$\operatorname{LnY}=0,911+0,291$ Ln Luas - 0,106LnTenaga kerja $+0,149$ Ln Pestisida - 0,063 LnPupuk organik - 0,146 LnPupuk kimia + 0,951 Dummy bencana

Hasil pendugaan model fungsi produksi dan model fungsi risiko produksi memberikan nilai koefisien determinasi $\left(\mathrm{R}^{2}\right)$ sebesar $80,2 \%$ dan $0,364 \%$ dengan nilai koefisien determinasi terkorelasi ( $\mathrm{R}^{2}$ adj) sebesar $78,9 \%$ dan $0,33 \%$. Nilai $\mathrm{R}^{2}$ pada fungsi produksi menunjukan bahwa $80,2 \%$ keragaman produksi padi dapat dijelaskan secara bersama-sama oleh faktor produksi luas, tenaga kerja, pestisida, pupuk organik, pupuk kimia, dan dummy bencana. Sedangkan sisanya sebesar 19,8\% dijelaskan oleh faktor lain diluar model. Nilai $\mathrm{R}^{2}$ pada fungsi risiko produksi menunjukan bahwa 36\% keragaman variance produksi padi dapat dijelaskan secara bersama-sama oleh faktor produksi tenaga kerja, pestisida, pupuk organik, pupuk kimia, dan dummy bencana. Sedangkan sisanya sebesar 63,6\% dijelaskan oleh faktor lain diluar model.

Tabel 1. Hasil pendugaan fungsi produksi dan fungsi risiko produksi usaha tani padi petani sampel di Desa Kedungprimpen, Kecamatan Kanor, Kabupaten Bojonegoro tahun 2016

\begin{tabular}{|c|c|c|c|c|}
\hline Variabel & Koefisien regresi & Simpangan baku koefisien & $\mathrm{T}$ & P-Value \\
\hline \multicolumn{5}{|c|}{ Fungsi Produksi } \\
\hline (Constant) & 4,856 & 1,194 & 4,067 & 0,000 \\
\hline Ln Luas & 0,141 & 0,167 & 0,842 & 0,402 \\
\hline Ln Tenaga kerja & 0,100 & 0,127 & 0,786 & 0,434 \\
\hline Ln Pestisida & $-0,176$ & 0,098 & $-1,802$ & $0,075^{*}$ \\
\hline Ln Pupuk organik & 0,136 & 0,128 & 1,068 & 0,288 \\
\hline Ln Pupuk kimia & 0,655 & 0,182 & 3,609 & $0,000^{*}$ \\
\hline Dummy bencana & $-2,384$ & 0,166 & $-14,349$ & $0,000^{*}$ \\
\hline \multicolumn{5}{|c|}{ Fungsi Risiko Produksi } \\
\hline (Constant) & 0,911 & 1,182 & 0,771 & 0,443 \\
\hline Ln Luas & 0,291 & 0,165 & 1,758 & $0,082^{*}$ \\
\hline Ln Tenaga kerja & $-0,106$ & 0,126 & $-0,846$ & 0,400 \\
\hline Ln Pestisida & 0,149 & 0,097 & 1,547 & $0,125^{* *}$ \\
\hline Ln Pupuk organik & $-0,063$ & 0,126 & $-0,501$ & 0,618 \\
\hline Ln Pupuk kimia & $-0,146$ & 0,180 & $-0,812$ & 0,419 \\
\hline Dummy bencana & 0,951 & 0,164 & 5,780 & $0,000^{*}$ \\
\hline
\end{tabular}

Keterangan: *) Signifikan pada $\alpha=10 \%, * *)$ Signifikan pada $\alpha=20 \%$ 
Hasil pendugaan fungsi produksi dan fungsi risiko produksi diperoleh nilai F-hitung sebesar 62,852 dan 7,331 yang berpengaruh nyata pada taraf nyata $10 \%$. Hal ini menunjukkan bahwa faktor-faktor produksi yang digunakan secara bersama-sama berpengaruh nyata terhadap produksi padi dan risiko produksi.

Variabel pestisida, pupuk kimia, dan dummy bencana berpengaruh nyata pada taraf kepercayaan 10\% terhadap produksi padi. Sedangkan untuk luas, tenaga kerja, dan pupuk organik tidak berpengaruh nyata pada taraf kepercayaan $10 \%$ terhadap produsi padi. Pada fungsi risiko produksi variabel input luas lahan, dan variabel dummy bencana signifikan pada taraf kepercayaan $10 \%$ dan variabel pestisida signifikan pada taraf kepercayaan $20 \%$. Faktor produksi lainnya seperti tenaga kerja, pupuk kimia, pupuk organik, tidak signifikan. Faktor produksi dan faktor risiko produksi secara rinci dijelaskan sebagai berikut :

\section{Luas lahan}

Input luas lahan memiliki tanda positif yang artinya setiap penambahan luas lahan akan meningkatkan produksi padi. Hasil estimasi sejalan dengan hasil penelitian Prabandari et al. (2013). Input luas lahan dalam hasil estimasi fungsi risiko produksi padi memiliki tanda positif yang artinya input lahan merupakan input yang risk increasing. Hasil estimasi variabel lahan meningkatkan risiko produksi sejalan dengan penelitian Fariyanti (2008), Fauziyah (2010), Tiedeman dan Lohmann (2012), dan Hidayati (2016). Namun, Prihtanti (2014) menemukan hasil yang berbeda dimana luas lahan merupakan input yang menurunkan risiko produksi.

\section{Tenaga Kerja}

Input tenaga kerja memiliki tanda positif yang artinya setiap penambahan tenaga kerja akan meningkatkan produksi padi. Hasil analisis sama dengan analisis yang dilakukan Fauziyah (2010), Rahayu (2011), Hidayati (2016), dan Rubinos et al. (2007). Koefisien parameter dugaan untuk variabel tenaga kerja pada hasil estimasi risiko produksi memiliki tanda negatif yang artinya setiap penambahan tenaga kerja akan mengakibatkan variance produksi padi menurun. Faktor produksi tenaga kerja dapat dikatakan sebagai faktor pengurang risiko (risk reducing factors). Hasil analisis sejalan dengan Fauziyah (2010) dan Nurhapsa (2013) dimana tenaga kerja merupakan input yang menurunkan risiko produksi. Berbeda dengan Hidayati (2016) yang menyatakan bahwa semakin tinggi penggunaan tenaga kerja pada usaha tani kubis maka risiko produksinya akan meningkat.

\section{Pestisida}

Koefisien parameter dugaan untuk variabel pestisida memiliki tanda negatif yang artinya setiap penambahan pestisida akan mengakibatkan produksi padi menurun. Hal ini disebabkan karena penggunaan pestisida tidak tepat guna. Koefisien parameter dugaan untuk variabel pestisida pada model fungsi risiko produksi memiliki tanda positif yang artinya setiap penambahan pestisida akan mengakibatkan variance produksi padi meningkat. Hasil analisis berbeda dengan Robbinson dan Barry (1987) yang menyatakan bahwa pestisida merupakan faktor pengurang risiko.

\section{Pupuk oganik}

Pupuk organik berpengaruh positif terhadap produksi padi. Pupuk organik digunakan sebagai pupuk dasar budidaya padi. Hasil pendugaan fungsi risiko produksi menunjukkan bahwa variabel pupuk organik merupakan variabel produksi yang dapat menurunkan risiko produksi. Faktor produksi pupuk organik dapat dikatakan sebagai faktor pengurang risiko (risk reducing factors). Hasil estimasi sejalan dengan penelitian Fauziyah (2010), Nurhapsa (2013), dan Hidayati (2016).

\section{Pupuk kimia}

Koefisien parameter dugaan untuk variabel pupuk kimia memiliki tanda positif yang artinya setiap penambahan pupuk kimia akan mengakibatkan produksi padi juga meningkat. Hasil estimasi variabel pupuk kimia berpengaruh nyata terhadap peningkatan produksi sesuai dengan hasil penelitian Nurhapsa (2013) dimana penambahan pupuk Urea dan Phonska berpengaruh nyata meningkatkan produksi. Hasil pendugaan fungsi risiko produksi menunjukkan bahwa variabel pupuk kimia merupakan variabel produksi yang dapat menurunkan risiko produksi. Faktor produksi pupuk kimia dapat dikatakan sebagai faktor pengurang risiko (risk reducing factors). Hasil penelitian sejalan dengan penelitian Fauziyah (2010) dimana pupuk kimia berupa Urea menurunkan risiko produksi. 


\section{Dummy bencana}

Nilai koefisien parameter dugaan untuk variabel bencana adalah negatif. Hal ini menunjukan bahwa produksi padi pada kondisi banjir lebih rendah daripada produksi padi pada kondisi normal. Nilai koefisien parameter dugaan untuk variabel banjir pada fungsi risiko produksi adalah positif. Hal ini berarti bahwa risiko produksi padi pada kondisi banjir (musim tanam II tahun 2013) lebih tinggi daripada kondisi normal (musim tanam II tahun 2015). Bencana merupakan faktor peningkat risiko (risk increasing factors).

\section{Preferensi Risiko Petani Padi di Kabupaten Bojonegoro}

Setelah diketahui tentang risiko produksi yang dihadapi oleh petani padi di Desa Kedungprimpen, Kecamatan Kanor maka perlu untuk mengetahui bagaimana preferensi risiko petani padi. Dalam melakukan estimasi terhadap nilai preferensi risiko petani atau nilai AR (absoluteriskaverse), petani dapat dikatakan riskaverse, risk neutral, dan risk taker apabila secara berturutturut mempunyai nilai $\mathrm{AR}>0, \mathrm{AR}=0$ dan $\mathrm{AR}<0$. Hasil analisis preferensi risiko petani terhadap penggunaan input dengan menggunakan model Arrow-Pratt dapat dilihat pada Tabel 2. Dapat dilihat bahwa penggunaan input lahan, tenaga kerja, pupuk organik, dan pupuk kimia bersifat risk taker, sedangkan penggunaan input pestisida risk averse. Penjelasan masing-masing preferensi risiko petani dalam penggunaan input akan dijelaskan sebagai berikut:

\section{Luas lahan}

Preferensi risiko petani terhadap penggunaan input luas lahan adalah risk taker. Petani yang bersifat risk taker akan berani mengalokasikan lahan lebih luas pada usaha tani tersebut. Hal ini ditunjukan oleh penggunaan luas lahan petani sampel rata-rata 0,88 ha. Hasil estimasi preferensi risiko dalam penggunaan lahan sejalan dengan Saptana et al. (2010), dan Fauziyah (2010), dimana ditemukan bahwa preferensi risiko petani tembakau pegunungan dengan sistem kemitraan terhadap input lahan bersifat risk taker.

\section{Tenaga kerja}

Preferensi risiko petani padi di Desa Kedungprimpen terhadap penggunaan tenaga kerja bersifat risk taker. Hal ini dapat dilihat dari kegiatan panen pada saat lahan petani terkena banjir pada musim tanam II tahun 2013. Petani tetap menggunakan tenaga kerja luar keluarga dengan upah yang besar bahkan terdapat petani yang mengeluarkan biaya upah tenaga kerja lebih besar dari hasil panen. Hasil estimasi preferensi risiko terhadap penggunaan input tenaga kerja berperilaku risk taker sejalan dengan penelitian Saptana (2010), Fauziyah (2010) dan Hidayati (2016).

\section{Pestisida}

Penggunaan input pestisida menunjukan bahwa petani risk averse atau menghindari risiko. Penggunaan pestisida petani sampel sangat beragam dengan merk dagang yang bervariasi. Penggunaan pestisida yang berbeda merk dagang dengan kegunaan yang sama membuktikan bahwa petani menghindari risiko dengan mengganti penggunaan pestisida jika diketahui pestisida tersebut kurang memberikan manfaat pada penanggulangan hama dan penyakit tanaman. Hasil estimasi sejalan dengan penelitian Saptana et al. (2010), Fauziyah (2010), dan Hidayati (2016).

\section{Pupuk oganik dan pupuk kimia}

Preferensi risiko petani pada penggunaan pupuk kimia dan pupuk organik menunjukan bahwa petani sampel merupakan orang yang menyukai risiko (risk taker). Hal ini dapat dilihat dari penggunaan pupuk kimia dengan dosis melebihi yang direkomendasikan. Pupuk kimia yang digunakan petani sampel diantaranya urea, NPK phonska, SP-36, ZA, KCL, dan TSP. Total rata-rata penggunaan pupuk kimia petani sampel mencapai 700 kg per hektar sedangkan dosis yang direkomendasikan oleh Dinas Pertanian hanya 330-350 kg per ha. Preferensi risiko petani risk taker terhadap pupuk kimia sejalan dengan penelitian Saptana (2011) dan Hidayati (2016).

Pengenalan pupuk organik kepada petani sampel di desa Kedungprimpen baru dimulai tahun 2013. Namun, jika dilihat dari komposisi penggunaan pupuk organik pada tahun 2013 menunjukan bahwa petani sampel tidak ragu untuk menggunakan pupuk organik tesebut meskipun baru mengenal. Penggunaan pupuk organik rata-rata petani sampel pada musim tanam II tahun 2013 mencapai 1.124,49 kg per ha. Pupuk organik digunakan petani sebagai pupuk dasar untuk menambah unsur hara tanaman. Petani mendapatkan pupuk organik secara mudah dengan harga yang murah, sehingga petani menyukai dalam penggunaan pupuk 
organik. Preferensi risiko petani risk taker terhadap pupuk organik sejalan dengan penelitian Saptana (2011) dan Hidayati (2016).

Apabila dilihat preferensi risiko petani untuk keseluruhan input yang digunakan, menunjukkan bahwa $100 \%$ petani padi yang ada di Desa Kedungprimpen bersifat risk taker. Hal ini menunjukan bahwa petani padi di Desa Kedungprimpen, Kecamatan Kanor, Kabupaten Bojonegoro berani menghadapi risiko.

Risiko banjir yang dihadapi petani di Desa Kedungprimpen yang telah berlangsung bertahun tahun dengan probabilitas terjadinya banjir yang merugikan selama lima tahun terakhir atau 10 musim tanam sebesar 0,3\%, menyebabkan petani di Desa Kedungprimpen lebih berani menghadapi risiko banjir. Meskipun banjir menyebabkan kerugian bagi petani, namun banjir tidak hanya memberikan dampak negatif melainkan juga dampak positif.

Dampak positif dari banjir diantaranya, yaitu banjir membawa lumpur dari sungai Bengawan Solo dengan kandungan unsur hara yang dibutuhkan oleh lahan sawah petani dan sebagai penetralisir lahan dari kandungan kimia akibat penggunaan pupuk kimia dan pestisida kimia. Sehingga musim tanam setelah banjir menjadi lebih produktif dibandingkan musim lainnya. Selain itu, luapan air sungai juga membawa ikan yang dapat dimanfaatkan oleh petani untuk konsumsi dan dijual. Kondisi banjir juga dimanfaatkan oleh petani untuk mencari penghasilan diluar usaha tani dengan menjadi buruh tani pada wilayah lain yang tidak terkena banjir. Hal ini yang menjadikan petani bersifat risk taker karena petani telah memiliki penghasilan lain apabila banjir merusak hasil produksi lahan petani.

\section{Implikasi Manajerial}

Implikasi manajerial yang dapat dikemukakan berkaitan dengan hasil penelitian ini, yaitu petani dapat menggunakan varietas tahan banjir yang telah disediakan oleh Dinas Pertanian Kabupaten
Bojonegoro, mengatur pola tanam, mengurangi penggunaan pestisida dan tidak menambah luas lahan garapan untuk mengurangi risiko produksi. Selanjutnya, pemerintah daerah dapat mengurangi sumber risiko banjir dengan membangun tanggul, bendungan, menyediakan pompa air, dan asuransi pertanian. Bagi perguruan tinggi dapat mengembangkan teknologi untuk mengurangi risiko produksi.

\section{KESIMPULAN DAN SARAN}

\section{Kesimpulan}

Penelitian ini dapat ditarik kesimpulan bahwa input luas lahan, tenaga kerja, dan pupuk organik akan meningkatkan produksi padi sedangkan pestisida akan mengakibatkan produksi padi menurun. Variabel dummy bencana menunjukan produksi padi pada kondisi banjir lebih rendah daripada produksi padi pada kondisi normal. Variabel luas lahan, pestisida, dan dummy bencana merupakan faktor peningkat risiko (risk increasing factors), sedangkan tenaga kerja, pupuk kimia dan pupuk organik merupakan faktor pengurang risiko (risk reducing factors).

Penggunaan input luas lahan, tenaga kerja, pupuk organik dan pupuk kimia bersifat risk taker, sedangkan penggunaan inputpestisidabersifatriskaverse. Preferensi risiko petani secara keseluruhan menunjukkan bahwa seluruh petani padi yang ada di Desa Kedungprimpen bersifat risk taker.

\section{Saran}

Berdasarkan kesimpulan maka saran yang dapat disampaikan, yaitu penyuluh pertanian dan petani dapat bekerja sama dengan baik dalam penentuan penggunaan input produksi seperti pestisida supaya dalam penggunaannya tepat guna. Selanjutnya, perlu adanya asuransi pertanian yang dapat memberikan perlindungan kepada petani padi di Desa Kedungprimpen sebagai antisipasi terhadap risiko produksi.

Tabel 2. Preferensi risiko produksi petani padi di Desa Kedungprimpen terhadap penggunaan input produksi

\begin{tabular}{lcc}
\hline \multicolumn{1}{c}{ Input produksi } & Rata-rata nilai AR & Preferensi risiko \\
\hline Lahan & $-0,0809$ & Risk taker \\
Tenaga kerja & $-4,1693 \mathrm{E}-06$ & Risk taker \\
Pestisida & $7,37 \mathrm{E}-05$ & Risk averse \\
Pupuk roganik & $-17,7061$ & Risk taker \\
Pupuk kimia & $-0,001505$ & Risk taker \\
\hline
\end{tabular}




\section{DAFTAR PUSTAKA}

Adisukma D. 2014. Strategi pengelolaan DAS Bengawan Solo di kabupaten Tuban dan Bojonegoro provinsi Jawa Timur. Sukoharjo: Seminar nasional pembangunan berkelanjutan di DAS Bengawan Solo.

[BPS Bojonegoro] Badan Pusat Statistik Provinsi Jawa Timur. 2016. Produksi Padi Kabupaten Bojonegoro Tahun 2009 - 2014. Jawa Timur: BPS.

Ellis F. 1988. Peasant Economics: Farm Household and Agricultural Development. Cambridge University Press, Cambridge.

Fariyanti A. 2008. Perilaku ekonomi rumah tangga petanisayuran dalammenghadapi resiko produksi dan harga produk di Kecamatan Pangalengan Kabupaten Bandung [disertasi]. Bogor: Sekolah Program Pascasarjana, Institut Pertanian Bogor.

Fauziah E, Hartoyo S, Kusnadi N, Kuntjoro SU. 2010. Analisis produktivitas usaha tani tembakau di Kabupaten Pamekasan. Jurnal Organisasi dan Manajemen 6(2):119-131.

Firdaus M. 2011. Ekonometrika Suatu Pendekatan Aplikatif. Jakarta: Bumi Aksara.

Fufa B, Hassan RM. 2003. Stochastic maize production technology and production risk analysis in Dadar District, East Ethiopia. Journal of Agricultural Economics 42(2):116-128.

Gujarati DN. 2007. Dasar-dasar Ekonometrika. Jakarta: Erlangga.

Hernanto F. 1989. Ilmu Usaha tani. Jakarta: Penebar Swadaya.

Hidayati, R. 2016. Pengaruh efisiensi teknis dan preferensi risiko petani terhadap penerapan usahatani kubis organik di Kecamatan Baso Kabupaten Agam Sumatera Barat [tesis]. Bogor: Sekolah Program Pascasarjana, Institut Pertanian Bogor.

[KLH] Kementrian Lingkungan Hidup. 2013. Profil Ekoregion Jawa DAS Bengawan Solo. http :// ppejawa.com/ekoregion/das-bengawas-solo/ [13 Januari 2016].

Kumbhakar CS. 2002. Specification and estimation of production risk, risk preferences and technical efficiency. American Journal Agricultural Economic 84 (1): 8-22.

Mahananto, Salyo S, Candra FA. 2009. Faktor-faktor yang memengaruhi produksi padi studi kasus di Kecamatan Nogosari, Boyolali, Jawa Tengah. WACANA 12(1):179-191.
Marfai MA. 2014. Analisis bencana banjir sebagai masukan dalam pembangunan berkelanjutan di DAS Bengawan Solo. Sukoharjo: Seminar nasional pembangunan berkelanjutan di DAS Bengawan Solo.

Nurhapsa. 2013. Analisis efisiensi teknis dan perilaku risiko petani serta pengaruhnya terhadap penerapan varietas unggul pada usahatani kentang di Kabupaten Enrekang Provinsi Sulawesi Selatan [disertasi]. Bogor: Sekolah Program Pascasarjana, Institut Pertanian Bogor.

Prabandari. 2013. Analisis faktor-Faktor yang memengaruhi produksi padi sawah pada daerah tengah dan hilir aliran sungai ayung (studi kasus subak mambal, Kabupaten Badung dan subak pagutan, Kota Denpasar). E-Jurnal Agribisnis dan Agrowisata 2(3):89-98.

Prihtanti TM. 2014. Analisis risiko berbagai luas pengusahaan lahan pada usahatani padi organik dan konvensional. AGRIC Jurnal Ilmu-Ilmu Pertanian 26(1\&2):29-36.

Purwanto A. 2014. Pengelolaan DAS secara terpadu dalam konteks otonomi daerah. Sukoharjo: Seminar nasional pembangunan berkelanjutan di DAS Bengawan Solo.

Rahayu RB. 2011. Preferensi risiko petani pada usahatani padi organik di Kabupaten Sragen [tesis]. Bogor: Institut Pertanian Bogor.

Robinson LJ, Barry PJ. 1987. The Competitive Firm's Response to Risk. Macmillan Publisher: London.

Rubinos R, Ana TJ, Purisima B. 2007. Comparative economic study of organic and conventional rice farming in Magsaysay, Davao Del Sur.10th National Convention on Statistics (NCS), EDSA Shangri-La Hotel,Manila.

Saptana, Daryanto A, Daryanto H, Kuntjoro K. 2010. Strategi manajemen risiko petani cabai merah pada lahan sawah dataran rendah di Jawa Tengah. Jurnal Manajemen \& Agribisis 7(2):115-131.

Setiawan, Kusrini. 2010. Ekonometrika. Jogjakarta: Andi Press.

Susetyo B. 2012. Statistika untuk Analisis Data Penelitian. Bandung: Refika Aditama.

Tiedemann T, Lohmann UL. 2012. Production risk and technical efficiency in organic and conventional agriculture: the case of arable farm in Germany. Journal of Agricultural Economics 64(1):7396. 